\title{
Comparison of Fused-Ring Electron Acceptors with One- and Multidimensional Conformations
}

Tengfei Li, ${ }^{\dagger, \#}$ Langxuan Yang, ${ }^{\dagger, \#}$ Yao Wu,${ }^{\star}$ Jiayu Wang, ${ }^{\dagger}$ Boyu Jia,${ }^{\dagger}$ Qin Hu, ${ }^{\ddagger}$, Thomas $^{\circ}$ P. Russell, ${ }^{\ddagger} \S$ and Xiaowei Zhan ${ }^{*} \dagger$

${ }^{\dagger}$ Department of Materials Science and Engineering, College of Engineering, Key Laboratory of Polymer Chemistry and Physics of Ministry of Education, Peking University, Beijing 100871, China.*Email: xwzhan@pku.edu.cn

${ }^{\ddagger}$ Department of Polymer Science and Engineering, University of Massachusetts Amherst, 120 Governors Drive, Amherst, Massachusetts 01003, United States

${ }^{\S}$ Materials Sciences Division, Lawrence Berkeley National Laboratory, 1 Cyclotron Road, Berkeley, California 94720, United States

${ }^{\#}$ These authors contributed equally to this work.

\section{Materials}

Unless stated otherwise, all the solvents and chemical reagents used were obtained commercially and used without further purification. THF was distilled from sodium benzophenone under nitrogen before use. Compounds $\mathbf{1}$ and $\mathbf{6}$ were purchased from Suna Tech Inc.; compound $\mathbf{2}$ was purchased from Bidepharmatech Inc.; compound $\mathbf{1 0}$ was purchased from $\mathrm{J} \& \mathrm{~K}$ Inc. $2 \mathrm{FIC}^{\mathrm{S} 1}$ and $\mathrm{F} 8 \mathrm{IC}^{\mathrm{S} 2}$ were synthesized 
according to our reported procedures. PTB7-Th was purchased from 1-Material Inc.; J71 and PM7 were purchased from Solarmer Materials Inc.; zinc acetate dihydrate, ethanolamine, and $\mathrm{MoO}_{3}$ were obtained from Sigma-Aldrich Inc.

\section{Synthesis}

Compound 3. To a three-necked round bottom flask were added compound $\mathbf{1}$ (1.0 g, $1.7 \mathrm{mmol})$, compound $2(670 \mathrm{mg}, 3.7 \mathrm{mmol}), \mathrm{Na}_{2} \mathrm{CO}_{3}(530 \mathrm{mg}, 5.0 \mathrm{mmol})$ and $\mathrm{DMF} /$ water $(10 \mathrm{~mL}, 4: 1)$. The mixture was deoxygenated with nitrogen for $30 \mathrm{~min}$. $\operatorname{Pd}(\mathrm{dppf}) \mathrm{Cl}_{2} \bullet \mathrm{DCM}(60 \mathrm{mg}, 0.07 \mathrm{mmol})$ was added under nitrogen. The mixture was stirred at $100{ }^{\circ} \mathrm{C}$ for $2 \mathrm{~h}$ and then cooled down to room temperature. Water (30 mL) was added and the mixture was extracted with dichloromethane $(3 \times 20 \mathrm{~mL})$. The organic phase was dried over anhydrous $\mathrm{Na}_{2} \mathrm{SO}_{4}$ and filtered. After removing the solvent from the filtrate, the residue was purified by column chromatography on silica gel using petroleum ether/dichloromethane (1:1) as the eluent yielding a yellow solid (700 mg, 78\%). ${ }^{1} \mathrm{H}$ NMR (400 MHz, $\left.\mathrm{CDCl}_{3}\right): \delta 7.73(\mathrm{~d}, J=8.0 \mathrm{~Hz}, 2 \mathrm{H}), 7.54(\mathrm{~d}, J=$ $5.2 \mathrm{~Hz}, 2 \mathrm{H}), 7.49(\mathrm{~d}, J=8.0 \mathrm{~Hz}, 2 \mathrm{H}), 7.47(\mathrm{~s}, 2 \mathrm{H}), 7.25(\mathrm{~d}, J=5.2 \mathrm{~Hz}, 2 \mathrm{H}), 4.19$ (q, $J$ $=6.8 \mathrm{~Hz}, 4 \mathrm{H}), 2.00(\mathrm{~m}, 4 \mathrm{H}), 1.09-1.20(\mathrm{~m}, 16 \mathrm{H}), 0.77(\mathrm{t}, J=7.0 \mathrm{~Hz}, 6 \mathrm{H}) .{ }^{13} \mathrm{C} \mathrm{NMR}$ (100 MHz, $\left.\mathrm{CD}_{2} \mathrm{Cl}_{2}\right): \delta 163.6,151.4,156.0,141.0,132.6,130.2,129.0,128.6,124.5$, 124.0, 119.4, 60.5, 55.4, 40.4, 31.6, 29.8, 23.9, 22.7, 14.3, 14.1. MS (MALDI-TOF): $m / z 642.3\left(\mathrm{M}^{+}\right)$.

Compound 4. To a suspension of magnesium turnings (150 mg, $6.2 \mathrm{mmol}$ ) and a little iodine in dry THF $(10 \mathrm{~mL})$ was added 1-bromo-4-hexylbenzene (1.5 g, $6.2 \mathrm{mmol})$ dropwise under nitrogen, and then the mixture was stirred at $45{ }^{\circ} \mathrm{C}$ for $2 \mathrm{~h}$. To a 
solution of compound $3(500 \mathrm{mg}, 0.77 \mathrm{mmol})$ in dry THF $(20 \mathrm{~mL})$ was added the prepared Grignard reagent dropwise at room temperature under nitrogen. The mixture was stirred at reflux for $12 \mathrm{~h}$ and then cooled down to room temperature. Saturated $\mathrm{NH}_{4} \mathrm{Cl}$ (aq., $20 \mathrm{~mL}$ ) was added and the mixture was extracted with dichloromethane $(3 \times 15 \mathrm{~mL})$. The organic phase was dried over anhydrous $\mathrm{Na}_{2} \mathrm{SO}_{4}$ and filtered. After removing the solvent, the orange residue was dissolved by octane $(10 \mathrm{~mL})$ and acetic acid $(5 \mathrm{~mL})$, then concentrated $\mathrm{H}_{2} \mathrm{SO}_{4}$ : acetic acid $(0.03: 1 \mathrm{~mL})$ was added. The mixture was stirred at $65^{\circ} \mathrm{C}$ for $12 \mathrm{~h}$ and then quenched with water. The organic layer was washed with water for three times and extracted with dichloromethane $(3 \times 15$ $\mathrm{mL}$ ), and was dried over anhydrous $\mathrm{Na}_{2} \mathrm{SO}_{4}$ and filtered. After removing the solvent from the filtrate, the residue was purified by column chromatography on silica gel using petroleum ether/dichloromethane (50:1) as the eluent yielding a yellow solid (520 mg, 62\%). ${ }^{1} \mathrm{H}$ NMR (300 MHz, $\mathrm{CD}_{2} \mathrm{Cl}_{2}$ ): $\delta 7.55$ (s, 2H), 7.44 (s, 2H), $7.30(\mathrm{~d}, J$ $=4.8 \mathrm{~Hz}, 2 \mathrm{H}), 7.11(\mathrm{~d}, J=8.4 \mathrm{~Hz}, 8 \mathrm{H}), 7.03(\mathrm{~d}, J=8.4 \mathrm{~Hz}, 8 \mathrm{H}), 6.99(\mathrm{~d}, J=4.8 \mathrm{~Hz}$, 2H), $2.53(\mathrm{t}, J=7.2 \mathrm{~Hz}, 8 \mathrm{H}), 2.04(\mathrm{~m}, 4 \mathrm{H}), 1.55(\mathrm{~m}, 8 \mathrm{H}), 1.28(\mathrm{~m}, 28 \mathrm{H}), 1.07(\mathrm{~m}$, 12H), $0.86(\mathrm{~m}, 12 \mathrm{H}), 0.74(\mathrm{~m}, 6 \mathrm{H}) .{ }^{13} \mathrm{C} \mathrm{NMR}\left(75 \mathrm{MHz}, \mathrm{CD}_{2} \mathrm{Cl}_{2}\right): \delta 156.4,153.2$, $151.4,142.5,141.7,141.5,139.5,136.6,128.6,128.0,127.8,123.3,117.5,114.1$, $62.9,54.9,40.9,35.7,32.0,31.7,31.6,30.0,29.4,24.2,22.8,14.2,14.1 . \mathrm{MS}$ (MALDI-TOF): $m / z 1162.7\left(\mathrm{M}^{+}\right)$.

Compound 5. A Vilsmeier reagent prepared with $\mathrm{POCl}_{3}(1.2 \mathrm{~mL})$ in DMF (6 $\mathrm{mL})$ was added to a solution of compound 4 (300 $\mathrm{mg}, 0.27 \mathrm{mmol})$ in 1,2-dichloroethane $(20 \mathrm{~mL})$ under the protection of nitrogen. After stirring at $85{ }^{\circ} \mathrm{C}$ 
for $12 \mathrm{~h}$, the mixture was quenched with saturated $\mathrm{CH}_{3} \mathrm{COONa}$ (aq.) and extracted with dichloromethane $(3 \times 15 \mathrm{~mL})$. The organic phase was dried over anhydrous $\mathrm{Na}_{2} \mathrm{SO}_{4}$ and filtered. After removing the solvent from the filtrate, the residue was purified by column chromatography on silica gel using petroleum ether/dichloromethane $(1: 1)$ as the eluent yielding a yellow solid $(280 \mathrm{mg}, 89 \%) .{ }^{1} \mathrm{H}$ NMR (300 MHz, $\left.\mathrm{CD}_{2} \mathrm{Cl}_{2}\right): \delta 9.81(\mathrm{~s}, 2 \mathrm{H}), 7.64(\mathrm{~s}, 2 \mathrm{H}), 7.63(\mathrm{~s}, 2 \mathrm{H}), 7.59$ (s, 2H), 7.11 (d, $J=8.1 \mathrm{~Hz}, 8 \mathrm{H}), 7.05(\mathrm{~d}, J=8.1 \mathrm{~Hz}, 8 \mathrm{H}), 2.53(\mathrm{t}, J=7.5 \mathrm{~Hz}, 8 \mathrm{H}), 2.08(\mathrm{~m}, 4 \mathrm{H})$, $1.50(\mathrm{~m}, 8 \mathrm{H}), 1.27(\mathrm{~m}, 28 \mathrm{H}), 1.06(\mathrm{~m}, 12 \mathrm{H}), 0.85(\mathrm{~m}, 12 \mathrm{H}), 0.73(\mathrm{~m}, 6 \mathrm{H}) .{ }^{13} \mathrm{C} \mathrm{NMR}$ $\left(75 \mathrm{MHz}, \mathrm{CD}_{2} \mathrm{Cl}_{2}\right): \delta 182.7,156.6,154.3,152.1,150.8,146.0,142.1,141.2,135.3$, $132.0,128.6,127.7,117.9,115.8,62.9,54.9,40.5,35.4,31.7,31.4,29.6,29.1,23.9$, 22.6, 13.8, 13.7. MS (MALDI-TOF): $m / z 1218.7\left(\mathrm{M}^{+}\right)$.

FXIC-1. To a three-necked round bottom flask were added compound 5 (130 mg, $0.11 \mathrm{mmol}), 2 \mathrm{FIC}(89 \mathrm{mg}, 0.39 \mathrm{mmol})$, pyridine $(0.2 \mathrm{~mL})$ and chloroform $(10 \mathrm{~mL})$. The mixture was deoxygenated with nitrogen for $30 \mathrm{~min}$ and then stirred at reflux for $12 \mathrm{~h}$. After cooling to room temperature, the mixture was poured into methanol (200 $\mathrm{mL}$ ) and filtered. The residue was purified by column chromatography on silica gel using petroleum ether/dichloromethane (1:1) as eluent yielding a blue solid (100 mg, 57\%). ${ }^{1} \mathrm{H}$ NMR (300 MHz, $\left.\mathrm{CD}_{2} \mathrm{Cl}_{2}\right): \delta 8.87(\mathrm{~s}, 2 \mathrm{H}), 8.51(\mathrm{~m}, 2 \mathrm{H}), 7.78(\mathrm{~s}, 2 \mathrm{H}), 7.76$ (s, 2H), $7.73(\mathrm{~m}, 2 \mathrm{H}), 7.69(\mathrm{~s}, 2 \mathrm{H}), 7.13(\mathrm{~d}, J=8.1 \mathrm{~Hz}, 8 \mathrm{H}), 7.07(\mathrm{~d}, J=8.1 \mathrm{~Hz}, 8 \mathrm{H})$, $2.55(\mathrm{t}, J=7.5 \mathrm{~Hz}, 8 \mathrm{H}), 2.13(\mathrm{~m}, 8 \mathrm{H}), 1.56(\mathrm{~m}, 8 \mathrm{H}), 1.28(\mathrm{~m}, 28 \mathrm{H}), 1.10(\mathrm{~m}, 12 \mathrm{H})$, $0.85(\mathrm{~m}, 12 \mathrm{H}), 0.76(\mathrm{~m}, 6 \mathrm{H}) .{ }^{13} \mathrm{C}$ NMR $\left(75 \mathrm{MHz}, \mathrm{CD}_{2} \mathrm{Cl}_{2}\right): \delta 185.9,160.8,158.4$, $157.8,155.6,153.0,152.6,142.7,142.3,140.8,140.7,139.8,138.5,136.7,135.8$, 
$134.8,128.6,127.7,121.2,118.4,116.9,114.7,114.4,114.2,112.6,112.4,69.6,62.9$, $54.9,40.4,35.4,31.7,31.4,31.4,29.7,29.1,24.0,22.6,13.8,13.7 . \mathrm{MS}$ (MALDI-TOF): $m / z 1644.5\left(\mathrm{M}^{+}\right)$.

Compound 7. To a three-necked round bottom flask were added compound $\mathbf{6}$ (500 mg, $0.60 \mathrm{mmol})$, compound 2 (680 mg, $2.9 \mathrm{mmol}), \mathrm{Na}_{2} \mathrm{CO}_{3}(380 \mathrm{mg}, 3.6 \mathrm{mmol})$ and $\mathrm{DMF} /$ water $(10 \mathrm{~mL}, 4: 1)$. The mixture was deoxygenated with nitrogen for 30 min. $\mathrm{Pd}(\mathrm{dppf}) \mathrm{Cl}_{2} \bullet \mathrm{DCM}(120 \mathrm{mg}, 0.15 \mathrm{mmol})$ was added under nitrogen. The mixture was stirred at $100{ }^{\circ} \mathrm{C}$ for $2 \mathrm{~h}$ and then cooled down to room temperature. Water (30 $\mathrm{mL})$ was added and the mixture was extracted with dichloromethane $(3 \times 20 \mathrm{~mL})$. The organic phase was dried over anhydrous $\mathrm{Na}_{2} \mathrm{SO}_{4}$ and filtered. After removing the solvent from the filtrate, the residue was purified by column chromatography on silica gel using petroleum ether/ethyl acetate (5:1) as the eluent yielding an orange solid (480 mg, 85\%). ${ }^{1} \mathrm{H}$ NMR (400 MHz, $\left.\mathrm{CD}_{2} \mathrm{Cl}_{2}\right): \delta 8.56(\mathrm{~s}, 4 \mathrm{H}), 7.74(\mathrm{~d}, J=8.0 \mathrm{~Hz}, 4 \mathrm{H})$, $7.50(\mathrm{~d}, J=6.4 \mathrm{~Hz}, 4 \mathrm{H}), 7.48(\mathrm{~d}, J=5.2 \mathrm{~Hz}, 4 \mathrm{H}), 7.20(\mathrm{~d}, J=5.2 \mathrm{~Hz}, 4 \mathrm{H}), 4.03(\mathrm{q}, J$ $=7.2 \mathrm{~Hz}, 8 \mathrm{H}), 1.08(\mathrm{t}, J=7.0 \mathrm{~Hz}, 12 \mathrm{H}) \cdot{ }^{13} \mathrm{C} \mathrm{NMR}\left(100 \mathrm{MHz}, \mathrm{CD}_{2} \mathrm{Cl}_{2}\right): \delta 163.3$, $150.9,141.4,141.3,138.1,133.1,131.9,130.2,129.2,128.6,124.5,119.8,60.8,14.2$. MS (MALDI-TOF): $m / z 944.0\left(\mathrm{M}^{+}\right)$.

Compound 8. To a solution of 1-bromo-4-hexylbenzene (2.5 g, $10 \mathrm{mmol})$ in dry THF (20 mL) at $-78^{\circ} \mathrm{C}$ was added $2.5 \mathrm{M} \mathrm{n}$-butyllithium in hexane (4.2 $\left.\mathrm{mL}, 11 \mathrm{mmol}\right)$ dropwise under nitrogen. The mixture was stirred at $-78{ }^{\circ} \mathrm{C}$ for $2 \mathrm{~h}$, and then a solution of compound $7(250 \mathrm{mg}, 0.25 \mathrm{mmol})$ in dry THF $(10 \mathrm{~mL})$ was added dropwise at $-78{ }^{\circ} \mathrm{C}$ under nitrogen. The mixture was stirred at room temperature for 
$12 \mathrm{~h}$. Brine $(20 \mathrm{~mL})$ was added and the mixture was extracted with dichloromethane $(3 \times 15 \mathrm{~mL})$. The organic phase was dried over anhydrous $\mathrm{Na}_{2} \mathrm{SO}_{4}$ and filtered. After removing the solvent, the red residue was dissolved by toluene $(20 \mathrm{~mL})$, then solid acid (Amberlyst 15, $150 \mathrm{mg}$ ) was added. The mixture was stirred at reflux for $12 \mathrm{~h}$ and then filtered. After removing the solvent from the filtrate, the residue was purified by column chromatography on silica gel using petroleum ether/dichloromethane $(10: 1)$ as the eluent yielding a brown solid (150 mg, 29\%). ${ }^{1} \mathrm{H}$ NMR (400 $\left.\mathrm{MHz}, \mathrm{CD}_{2} \mathrm{Cl}_{2}\right): \delta$ $8.53(\mathrm{~s}, 4 \mathrm{H}), 7.58(\mathrm{~s}, 4 \mathrm{H}), 7.28(\mathrm{~d}, J=4.8 \mathrm{~Hz}, 4 \mathrm{H}), 7.19$ (d, $J=8.0 \mathrm{~Hz}, 16 \mathrm{H}), 7.09$ (d, $J=8.0 \mathrm{~Hz}, 16 \mathrm{H}), 6.99(\mathrm{~d}, J=4.8 \mathrm{~Hz}, 4 \mathrm{H}), 2.59(\mathrm{t}, J=7.8 \mathrm{~Hz}, 16 \mathrm{H}), 1.58(\mathrm{~m}, 16 \mathrm{H})$, $1.28(\mathrm{~m}, 48 \mathrm{H}), 0.87(\mathrm{~m}, 24 \mathrm{H}) .{ }^{13} \mathrm{C} \mathrm{NMR}\left(75 \mathrm{MHz}, \mathrm{CD}_{2} \mathrm{Cl}_{2}\right): \delta 156.1,155.9,142.0$ $141.6,141.3,140.0,138.5,136.4,128.5,128.1,125.9,123.2,118.0,117.4,63.1,35.7$, 31.9, 31.5, 29.3, 22.7, 14.2. MS (MALDI-TOF): $m / z 1986.8\left(\mathrm{MH}^{+}\right)$.

Compound 9. A Vilsmeier reagent prepared with $\mathrm{POCl}_{3}(0.3 \mathrm{~mL})$ in DMF (1.5 $\mathrm{mL})$ was added to a solution of compound $\mathbf{8}(70 \mathrm{mg}, 0.04 \mathrm{mmol})$ in 1,2-dichloroethane $(10 \mathrm{~mL})$ under the protection of nitrogen. After stirring at $85{ }^{\circ} \mathrm{C}$ for $12 \mathrm{~h}$, the mixture was quenched with saturated $\mathrm{CH}_{3} \mathrm{COONa}$ (aq.) and extracted with dichloromethane $(3 \times 15 \mathrm{~mL})$. The organic phase was dried over anhydrous $\mathrm{Na}_{2} \mathrm{SO}_{4}$ and filtered. After removing the solvent from the filtrate, the residue was purified by column chromatography on silica gel using dichloromethane as the eluent yielding a red solid (46 mg, 74\%). ${ }^{1} \mathrm{H}$ NMR (300 MHz, $\left.\mathrm{CD}_{2} \mathrm{Cl}_{2}\right): \delta 9.80(\mathrm{~s}, 4 \mathrm{H})$, 8.65(s, 4H), $7.74(\mathrm{~s}, 4 \mathrm{H}), 7.68(\mathrm{~s}, 4 \mathrm{H}), 7.21(\mathrm{~m}, 16 \mathrm{H}), 7.16(\mathrm{~m}, 16 \mathrm{H}), 2.56(\mathrm{~m}, 16 \mathrm{H})$, $1.60(\mathrm{~m}, 16 \mathrm{H}), 1.29(\mathrm{~m}, 48 \mathrm{H}), 0.89(\mathrm{~m}, 24 \mathrm{H}) .{ }^{13} \mathrm{C} \mathrm{NMR}\left(75 \mathrm{MHz}, \mathrm{CD}_{2} \mathrm{Cl}_{2}\right): \delta .183 .2$ 
$157.5,157.0,150.4,147.0,142.7,141.9,141.3,141.1,139.2,135.9,132.4,129.1$, $128.2,119.4,118.9,63.8,35.9,32.1,31.9,29.5,23.0,14.3$. MS (MALDI-TOF): $m / z$ $2097.1\left(\mathrm{M}^{+}\right)$.

FXIC-2. To a three-necked round bottom flask were added compound 9 (46 mg, $0.02 \mathrm{mmol}), 2 \mathrm{FIC}(37 \mathrm{mg}, 0.16 \mathrm{mmol})$, pyridine $(0.2 \mathrm{~mL})$ and chloroform $(10 \mathrm{~mL})$. The mixture was deoxygenated with nitrogen for $30 \mathrm{~min}$ and then stirred at reflux for $12 \mathrm{~h}$. After cooling to room temperature, the mixture was poured into methanol (200 $\mathrm{mL}$ ) and filtered. The residue was purified by column chromatography on silica gel using petroleum ether/dichloromethane (1:1) as eluent yielding a blue solid (40 mg, 62\%). ${ }^{1} \mathrm{H}$ NMR (300 MHz, $\left.\mathrm{CD}_{2} \mathrm{Cl}_{2}\right): \delta 8.84(\mathrm{~s}, 4 \mathrm{H}), 8.78(\mathrm{~s}, 4 \mathrm{H}), 8.36(\mathrm{~m}, 4 \mathrm{H}), 7.82$ (s, 4H), $7.81(\mathrm{~s}, 4 \mathrm{H}), 7.43(\mathrm{t}, J=7.5 \mathrm{~Hz}, 4 \mathrm{H}), 7.19(\mathrm{~m}, 32 \mathrm{H}), 2.60(\mathrm{~m}, 16 \mathrm{H}), 1.60(\mathrm{~m}$, 16H), $1.27(\mathrm{~m}, 48 \mathrm{H}), 0.85(\mathrm{~m}, 24 \mathrm{H}) .{ }^{13} \mathrm{C} \mathrm{NMR}\left(75 \mathrm{MHz}, \mathrm{CD}_{2} \mathrm{Cl}_{2}\right): \delta 185.4,160.3$, $158.3,158.0,157.6,156.0,152.7,142.7,142.6,141.2,141.1,140.0,139.2,138.4$, $136.0,134.4,128.8,127.9,121.1,120.5,119.0,114.8,114.5,114.0,113.9,112.3$, 63.3, 35.5, 31.7, 29.7, 29.1, 22.60, 13.8. MS (MALDI-TOF): $m / z 2946.8\left(\mathrm{M}^{+}\right)$.

Compound 11. To a three-necked round bottom flask were added compound $\mathbf{1 0}$ (1.0 g, $1.3 \mathrm{mmol})$, compound 2 (1.4 g, $5.7 \mathrm{mmol}), \mathrm{Pd}\left(\mathrm{PPh}_{3}\right)_{4}(290 \mathrm{mg}, 0.25 \mathrm{mmol})$, $\mathrm{K}_{2} \mathrm{CO}_{3}(2.7 \mathrm{~g}, 20 \mathrm{mmol})$ and toluene/water $(25 \mathrm{~mL}, 4 / 1)$. The mixture was deoxygenated with nitrogen for $30 \mathrm{~min}$ and then stirred at $110{ }^{\circ} \mathrm{C}$ for $48 \mathrm{~h}$. After cooled down to room temperature, Brine $(30 \mathrm{~mL})$ was added and the mixture was extracted with dichloromethane $(3 \times 15 \mathrm{~mL})$. The organic phase was dried over anhydrous $\mathrm{Na}_{2} \mathrm{SO}_{4}$ and filtered. After removing the solvent from the filtrate, the 
residue was purified by column chromatography on silica gel using dichloromethane as the eluent yielding a yellow solid (730 mg, 64\%). ${ }^{1} \mathrm{H}$ NMR (300 $\left.\mathrm{MHz}, \mathrm{CD}_{2} \mathrm{Cl}_{2}\right): \delta$ $7.95(\mathrm{~d}, J=7.8 \mathrm{~Hz}, 4 \mathrm{H}), 7.60(\mathrm{~d}, J=7.8 \mathrm{~Hz}, 4 \mathrm{H}), 7.41(\mathrm{~d}, J=5.4 \mathrm{~Hz}, 4 \mathrm{H}), 7.18(\mathrm{~d}, J$ $=5.4 \mathrm{~Hz}, 4 \mathrm{H}), 7.00(\mathrm{~s}, 4 \mathrm{H}), 3.93(\mathrm{q}, J=7.2 \mathrm{~Hz}, 8 \mathrm{H}), 0.94(\mathrm{t}, J=7.2 \mathrm{~Hz}, 12 \mathrm{H}) .{ }^{13} \mathrm{C}$ NMR (75 MHz, $\left.\mathrm{CD}_{2} \mathrm{Cl}_{2}\right): \delta 163.4,149.9,148.6,141.9,133.9,130.4,129.1,125.8$, 124.6, 120.4, 66.3, 60.8, 14.2. MS (MALDI-TOF): $m / z$ 931.9 $\left(\mathrm{M}^{+}\right)$.

Compound 12. To a suspension of magnesium turnings (240 mg, $10 \mathrm{mmol}$ ) and a little iodine in dry THF $(10 \mathrm{~mL})$ was added 1-bromo-4-hexylbenzene $(2.3 \mathrm{~g}, 9.6$ mmol) dropwise under nitrogen, and then the mixture was stirred at reflux for $2 \mathrm{~h}$. To a solution of compound 11 (300 mg, $0.32 \mathrm{mmol})$ in dry THF $(20 \mathrm{~mL})$ was added the prepared Grignard reagent dropwise at room temperature under nitrogen. The mixture was stirred at reflux for $12 \mathrm{~h}$ and then cooled down to room temperature. Saturated $\mathrm{NH}_{4} \mathrm{Cl}$ (aq., $20 \mathrm{~mL}$ ) was added and the mixture was extracted with dichloromethane $(3 \times 15 \mathrm{~mL})$. The organic phase was dried over anhydrous $\mathrm{Na}_{2} \mathrm{SO}_{4}$ and filtered. After removing the solvent, the orange residue was dissolved by octane $(10 \mathrm{~mL})$ and acetic acid $(5 \mathrm{~mL})$, then concentrated $\mathrm{H}_{2} \mathrm{SO}_{4}$ : acetic acid $(0.03: 1 \mathrm{~mL})$ was added dropwise, the mixture was stirred at $70{ }^{\circ} \mathrm{C}$ for $12 \mathrm{~h}$ and then quenched with water. The organic layer was washed with water for three times and extracted with dichloromethane $(3 \times$ $15 \mathrm{~mL}$ ), and was dried over anhydrous $\mathrm{Na}_{2} \mathrm{SO}_{4}$ and filtered. After removing the solvent from the filtrate, the residue was purified by column chromatography on silica gel using petroleum ether/dichloromethane (10:1) as the eluent yielding a yellow solid (70 mg, 11\%). ${ }^{1} \mathrm{H}$ NMR (300 MHz, $\left.\mathrm{CD}_{2} \mathrm{Cl}_{2}\right): \delta 7.76(\mathrm{~s}, 4 \mathrm{H}), 7.21(\mathrm{~d}, J=5.1 \mathrm{~Hz}, 4 \mathrm{H})$, 
$7.15(\mathrm{~d}, J=8.1 \mathrm{~Hz}, 16 \mathrm{H}), 7.08(\mathrm{~d}, J=8.1 \mathrm{~Hz}, 16 \mathrm{H}), 6.94(\mathrm{~s}, 4 \mathrm{H}), 6.91(\mathrm{~d}, J=5.1 \mathrm{~Hz}$ 4H), $2.56(\mathrm{t}, J=7.2 \mathrm{~Hz}, 16 \mathrm{H}), 1.57(\mathrm{~m}, 16 \mathrm{H}), 1.31(\mathrm{~m}, 48 \mathrm{H}), 0.88(\mathrm{~m}, 24 \mathrm{H}) .{ }^{13} \mathrm{C}$ NMR (75 MHz, $\left.\mathrm{CD}_{2} \mathrm{Cl}_{2}\right): \delta 156.4,154.2,148.8,142.1,141.7,140.7,139.9,137.1$, $128.4,128.1,127.9,122.8,117.7,115.3,62.8,35.5,31.8,31.5,29.2,22.6,13.9 . \mathrm{MS}$ (MALDI-TOF): $m / z 1974.9\left(\mathrm{MH}^{+}\right)$.

Compound 13. A Vilsmeier reagent prepared with $\mathrm{POCl}_{3}(0.25 \mathrm{~mL})$ in $\mathrm{DMF}$ (1.5 mL) was added to a solution of compound $12(60 \mathrm{mg}, 0.03 \mathrm{mmol})$ in 1,2-dichloroethane $(20 \mathrm{~mL})$ under the protection of nitrogen. After stirring at $85{ }^{\circ} \mathrm{C}$ for $12 \mathrm{~h}$, the mixture was quenched with saturated $\mathrm{CH}_{3} \mathrm{COONa}(\mathrm{aq})$ and extracted with dichloromethane $(3 \times 15 \mathrm{~mL})$. The organic phase was dried over anhydrous $\mathrm{Na}_{2} \mathrm{SO}_{4}$ and filtered. After removing the solvent from the filtrate, the residue was purified by column chromatography on silica gel using petroleum ether/dichloromethane $(1: 1)$ as the eluent yielding a yellow solid $(30 \mathrm{mg}, 41 \%) .{ }^{1} \mathrm{H}$ NMR (400 MHz, $\left.\mathrm{CD}_{2} \mathrm{Cl}_{2}\right): \delta 9.72(\mathrm{~s}, 4 \mathrm{H}), 7.87(\mathrm{~s}, 4 \mathrm{H}), 7.58(\mathrm{~s}, 4 \mathrm{H}), 7.16(\mathrm{~d}, J=8.0$ Hz, 16H), $7.11(\mathrm{~m}, 16 \mathrm{H}), 7.10(\mathrm{~s}, 4 \mathrm{H}), 2.57$ (t, $J=8.0 \mathrm{~Hz}, 16 \mathrm{H}), 1.58(\mathrm{~m}, 16 \mathrm{H}), 1.25$ (m, 48H), $0.88(\mathrm{~m}, 24 \mathrm{H}) .{ }^{13} \mathrm{C} \mathrm{NMR}\left(100 \mathrm{MHz}, \mathrm{CD}_{2} \mathrm{Cl}_{2}\right): \delta 182.8,156.9,155.8,150.0$ 149.0, 146.6, 142.4 141.9, 141.0, 136.4, 131.9, 128.8, 127.9, 118.6, 117.4, 63.3, 35.6, 31.8, 31.6, 29.3, 27.2, 14.0. MS (MALDI-TOF): $m / z 2086.1\left(\mathrm{MH}^{+}\right)$.

FXIC-3. To a three-necked round bottom flask were added compound 13 (30 mg, $0.014 \mathrm{mmol}), 2$ FIC (25 mg, $0.11 \mathrm{mmol})$, pyridine $(0.15 \mathrm{~mL})$ and chloroform $(10 \mathrm{~mL})$. The mixture was deoxygenated with nitrogen for $30 \mathrm{~min}$ and then stirred at reflux for $12 \mathrm{~h}$. After cooling to room temperature, the mixture was poured into methanol (200 
$\mathrm{mL}$ ) and filtered. The residue was purified by column chromatography on silica gel using petroleum ether/dichloromethane (3:2) as eluent yielding a blue solid (20 mg, 47\%). ${ }^{1} \mathrm{H}$ NMR (300 MHz, $\left.\mathrm{CD}_{2} \mathrm{Cl}_{2}\right): \delta 8.77$ (s, 4H), $8.46(\mathrm{~m}, 4 \mathrm{H}), 7.96$ (s, 4H), 7.71 (s, 4H), $7.59(\mathrm{~m}, 4 \mathrm{H}), 7.29(\mathrm{~s}, 4 \mathrm{H}), 7.20(\mathrm{~m}, 16 \mathrm{H}), 7.18(\mathrm{~m}, 16 \mathrm{H}), 2.58(\mathrm{t}, J=8.0 \mathrm{~Hz}$ 16H), $1.61(\mathrm{~m}, 16 \mathrm{H}), 1.28(\mathrm{~m}, 48 \mathrm{H}), 0.87(\mathrm{~m}, 24 \mathrm{H}) .{ }^{13} \mathrm{C}$ NMR was not obtained due to the limited solubility and low signal-to-noise ratio. MS (MALDI-TOF): $m / z 2933.9$ $\left(\mathrm{M}^{+}\right)$

\section{Characterization}

The ${ }^{1} \mathrm{H}$ and ${ }^{13} \mathrm{C}$ NMR spectra were recorded using a Bruker AVANCE 300 or 400 $\mathrm{MHz}$ spectrometer. Mass spectra were recorded using Bruker Daltonics Biflex III MALDI-TOF Analyzer in the MALDI mode. UV-vis absorption spectra (solution in chloroform, thin film using quartz substrate) were measured using a $\mathrm{J} \Lambda \mathrm{SCO}$ V-570 spectrophotometer. Electrochemical measurements were carried out under nitrogen in a solution of tetra-n-butylammonium hexafluorophosphate $\left(\left[{ }^{n} \mathrm{Bu}_{4} \mathrm{~N}\right]^{+}\left[\mathrm{PF}_{6}\right]^{-}\right)(0.1 \mathrm{M})$ in $\mathrm{CH}_{3} \mathrm{CN}$ employing a computer-controlled CHI660C electrochemical workstation, glassy carbon working electrode coated with FXIC-1, FXIC-2, or FXIC-3 film, a platinum-wire auxiliary electrode, and an $\mathrm{Ag} / \mathrm{AgCl}$ reference electrode. The energy levels were referenced to a ferrocenium/ferrocene $\left(\mathrm{FeCp}_{2}{ }^{+/ 0}\right)$ couple using ferrocene as an internal standard. Thermogravimetric analysis measurements were performed using a thermogravimetric analyzer (Q600 TGA-DSC-DTA) under flowing nitrogen gas at a heating rate of $10{ }^{\circ} \mathrm{C} \mathrm{min}^{-1}$. The nanoscale morphology of the blend films was observed using an atomic force microscope (Dimension Icon, Bruker) in tapping 
mode.

\section{Molecular Modelling}

Density functional theory calculations were performed with the Gaussian 09 program, ${ }^{\mathrm{S} 3}$ using the B3LYP functional. ${ }^{\mathrm{S} 4 \mathrm{~S} 5}$ All-electron double- $\xi$ valence basis sets with polarization functions $6-31 \mathrm{G}^{*}$ were used for all atoms. ${ }^{\mathrm{S} 6}$ Geometry optimizations were performed with full relaxation of all atoms in gas phase without solvent effects. Vibration frequency calculation was performed to check that the stable structures had no imaginary frequency.

\section{Grazing Incidence Wide-angle X-ray Scattering}

Grazing incidence x-ray diffraction (GIXD) characterization of active layer was performed at beamline 7.3.3, Advanced Light Source (ALS), Lawrence Berkeley National Lab (LBNL). X-ray energy was $10 \mathrm{keV}$ and operated in top off mode. The scattering intensity was recorded on a 2D image plate (Pilatus $2 \mathrm{M}$ ) with a pixel size of $0.172 \mathrm{~mm}$ by $0.172 \mathrm{~mm}$. The samples were $\sim 10 \mathrm{~mm}$ long in the direction of the beam path, and the detector was located at a distance of $270 \mathrm{~mm}$ from the sample center (distance calibrated by $\mathrm{AgB}$ reference). The incidence angle was chosen to be $0.16^{\circ}$ (above critical angle) for GIXD measurement. ${ }^{\mathrm{S}-\mathrm{S} 9}$ OSC samples were prepared on PEDOT:PSS covered Si wafers in a similar manner to the OSC devices.

\section{Resonant Soft X-ray Scattering}

R-SoXS was performed at beamline 11.0.1.2, ALS, LBNL. Samples for R-SoXS measurements were prepared on a PEDOT: PSS modified Si substrate under the same conditions as used for OSC device fabrication, and then transferred by floating in 
water to a $1.5 \mathrm{~mm} \times 1.5 \mathrm{~mm}, 100$-nm thick $\mathrm{Si}_{3} \mathrm{~N}_{4}$ membrane supported by a $5 \mathrm{~mm} \times 5$ mm, $200 \mathrm{~mm}$ thick Si frame (Norcada Inc.).

\section{Fabrication and Characterization of OSCs}

The OSCs have an inverted structure of $\mathrm{ITO} / \mathrm{ZnO} /$ active layer $/ \mathrm{MoO}_{3} / \mathrm{Ag}$. Patterned ITO glass (sheet resistance $=15 \Omega$ ) was precleaned in an ultrasonic bath with acetone and isopropanol, and treated in an ultraviolet-ozone chamber (Jelight Company, USA) for $20 \mathrm{~min}$. ZnO layer (ca. $30 \mathrm{~nm}$ ) was spin-coated at $4000 \mathrm{rpm}$ onto the ITO glass from $\mathrm{ZnO}$ precursor solution $\left(100 \mathrm{mg} \mathrm{Zn}\left(\mathrm{CH}_{3} \mathrm{COO}\right)_{2} \cdot 2 \mathrm{H}_{2} \mathrm{O}\right.$ and 28.29 $\mu \mathrm{L}$ ethanolamine dissolved in $973 \mu \mathrm{L}$ 2-methoxyethanol), and then baked at $200{ }^{\circ} \mathrm{C}$ for 30 min. For PTB7-Th-based devices, a mixture of PTB7-Th:FXIC series or PTB7-Th:F8IC:FXIC series (12 $\mathrm{mg} \mathrm{mL}^{-1}$ in total) in $\mathrm{CHCl}_{3}$ without or with DIO was stirred at room temperature for $1 \mathrm{~h}$ and then spin-coated at $1600 \mathrm{rpm}$ or $2000 \mathrm{rpm}$ on the $\mathrm{ZnO}$ layer to form a photoactive layer $(c a .90 \mathrm{~nm})$. For J71-based devices, a mixture of $\mathrm{J} 71$ :FXIC-1 3 $\left(12 \mathrm{mg} \mathrm{mL}^{-1}\right.$ in total $)$ in $\mathrm{CHCl}_{3}$ was stirred at $45{ }^{\circ} \mathrm{C}$ for $1 \mathrm{~h}$ and then spin-coated at $1600 \mathrm{rpm}$ on the $\mathrm{ZnO}$ layer and annealed at $110{ }^{\circ} \mathrm{C}$ for $10 \mathrm{~min}$ to form a photoactive layer (ca. $100 \mathrm{~nm})$. For PM7-based devices, PM7:FXIC-1 3 mixture (20 $\mathrm{mg} \mathrm{mL}^{-1}$ in total) in 1,2-dichlorobenzene with 0.2 vol \% DIO was stirred at room temperature for $12 \mathrm{~h}$ and then spin-coated at $2000 \mathrm{rpm}$ on the $\mathrm{ZnO}$ layer and annealed at $120{ }^{\circ} \mathrm{C}$ for $10 \mathrm{~min}$ to form a photoactive layer ( $c a .100 \mathrm{~nm}$ ). The $\mathrm{MoO}_{3}$ layer $(c a .5 \mathrm{~nm})$ and $\mathrm{Ag}$ electrode $(c a .80 \mathrm{~nm})$ were slowly evaporated onto the surface of the photoactive layer under vacuum $\left(c a \cdot 10^{-5} \mathrm{~Pa}\right)$. The active area of the device was $c a .4 \mathrm{~mm}^{2}$. The devices were not masked and the active area of devices 
was measured by optical microscopy. The $J-V$ curve was measured using a computer-controlled B2912A Precision Source/Measure Unit (Agilent Technologies). An XES-70S1 (SAN-EI Electric Co., Ltd.) solar simulator (AAA grade, $70 \times 70 \mathrm{~mm}^{2}$ photobeam size) coupled with AM 1.5 G solar spectrum filters was used as the light source, and the optical power at the sample was $100 \mathrm{~mW} \mathrm{~cm}{ }^{-2}$. A $2 \times 2 \mathrm{~cm}^{2}$ monocrystalline silicon reference cell (SRC-1000-TC-QZ) was purchased from VLSI Standards Inc. The EQE spectra were measured using Solar Cell Spectral Response Measurement System QE-R3011 (Enlitech Co., Ltd.). The light intensity at each wavelength was calibrated using a standard single crystal Si photovoltaic cell. For light stability test, we measured the photovoltaic performance of the unencapsulated devices under continuous AM 1.5G illumination at $100 \mathrm{~mW} \mathrm{~cm}^{-2}$ in glove box for a certain time. For thermal stability test, we heated the unencapsulated devices at 100 ${ }^{\circ} \mathrm{C}$ in glove box for a certain time and measured the photovoltaic performance of the devices under AM 1.5G illumination at $100 \mathrm{~mW} \mathrm{~cm}^{-2}$.

\section{Mobility Measurements}

Electron-only devices were fabricated using the architectures of $\mathrm{Al} /$ acceptor or PTB7-Th:acceptor/Al. Al (ca. $80 \mathrm{~nm}$ ) was evaporated onto pre-cleaned glass under vacuum, acceptor or PTB7-Th:acceptor blend $(c a .80 \mathrm{~nm})$ was spin-coated, and then Al (ca. $50 \mathrm{~nm}$ ) was evaporated under vacuum. Hole-only devices were fabricated using the architecture of ITO/PEDOT: PSS/PTB7-Th:acceptor/Au. The pre-cleaned ITO glass was spin-coated with PEDOT: PSS (ca. $35 \mathrm{~nm})$, then PTB7-Th:acceptor blend (ca. $80 \mathrm{~nm})$ was spin-coated as active layer, then Au (ca. $30 \mathrm{~nm})$ was 
evaporated under vacuum $\left(c a \cdot 10^{-5} \mathrm{~Pa}\right)$ at a low speed $(1 \AA / 5 \mathrm{~s})$ to avoid the penetration of $\mathrm{Au}$ atoms into the active layer. The mobility was extracted by fitting the current density-voltage curves using space charge limited current (SCLC). ${ }^{\mathrm{S} 10}$ The equation is as follows.

$$
J=(9 / 8) \mu \varepsilon_{\mathrm{r}} \varepsilon_{0} V^{2} \exp \left(0.89\left(V / E_{0} d\right)^{0.5}\right) / d^{3}
$$

where $J$ is current density, $\mu$ is hole or electron mobility, $\varepsilon_{\mathrm{r}}$ is relative dielectric constant, $\varepsilon_{0}$ is permittivity of free space, $V=V_{\text {appl }}-V_{\text {bi }}$, where $V_{\text {appl }}$ is the applied voltage to the device, and $V_{\mathrm{bi}}$ is the built-in voltage due to the difference in work function of the two electrodes (for hole-only diodes, $V_{\mathrm{bi}}$ is $0.2 \mathrm{~V}$; for electron-only diodes, $V_{\mathrm{bi}}$ is $\left.0 \mathrm{~V}\right) . E_{0}$ is characteristic field, $d$ is the thickness of organic layer. The thickness of organic layer was measured on DektakXT (Bruker). The $J-V$ curves of the devices are plotted as $\ln \left[J d^{3} /\left(V_{\text {appl }}-V_{\mathrm{bi}}\right)^{2}\right]$ versus $\left[\left(V_{\text {appl }}-V_{\mathrm{bi}}\right) / d\right]^{0.5}$.

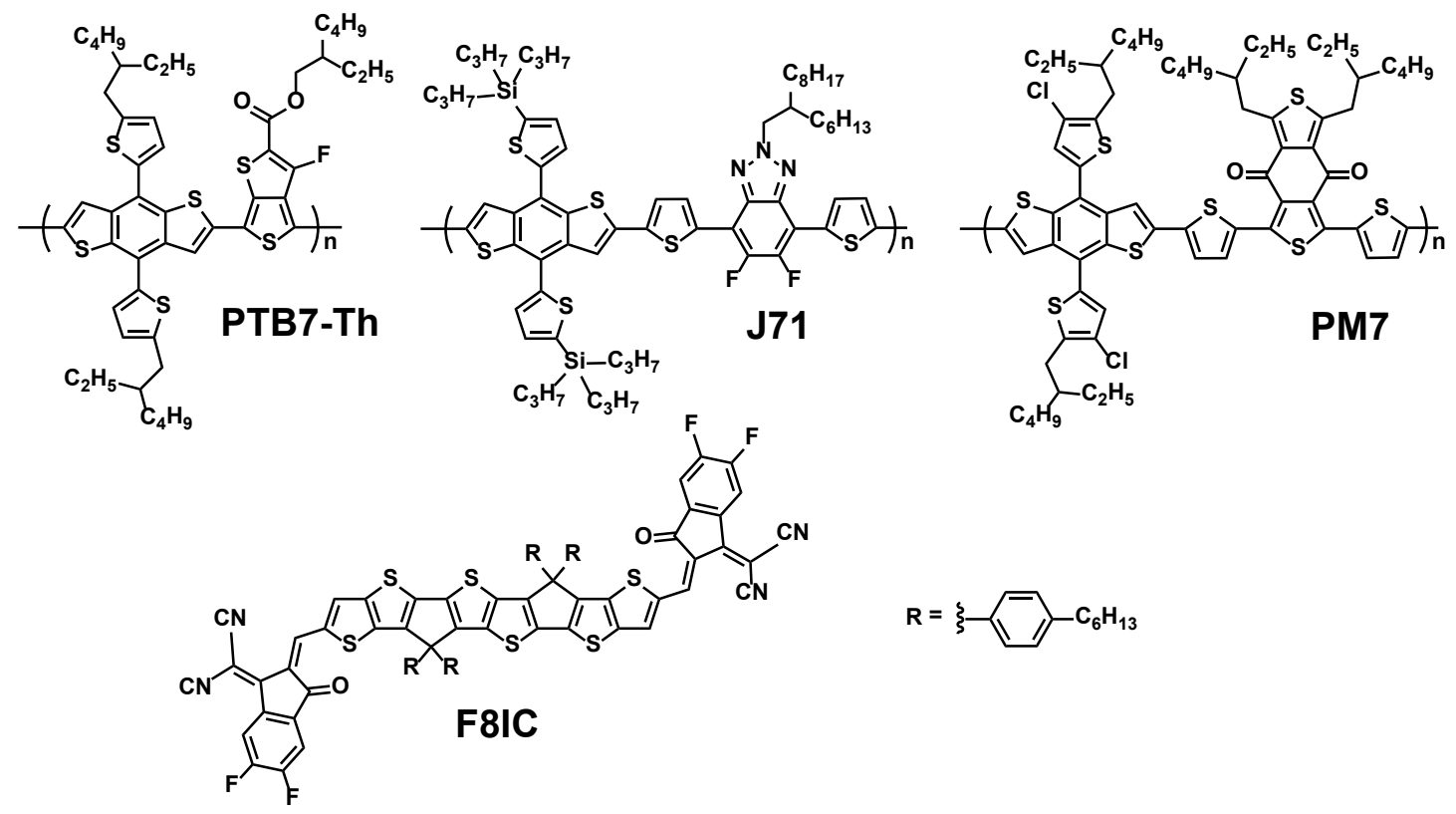

Chart S1. Chemical structures of PTB7-Th, J71, PM7, and F8IC. 


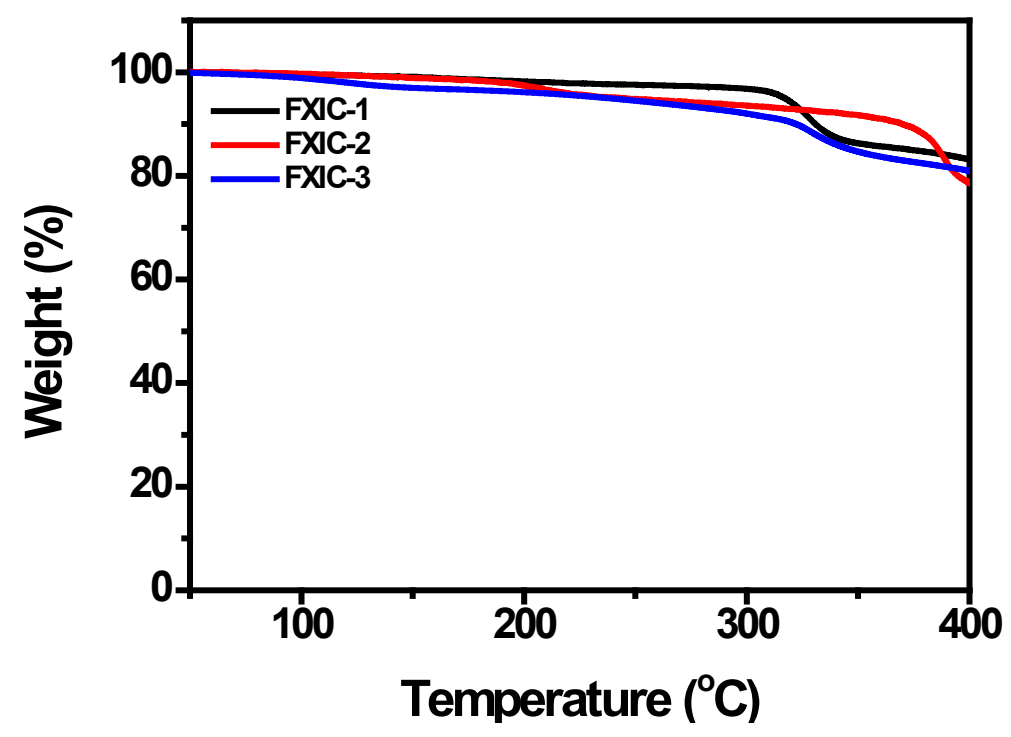

Figure S1. TGA curves of FXIC series.

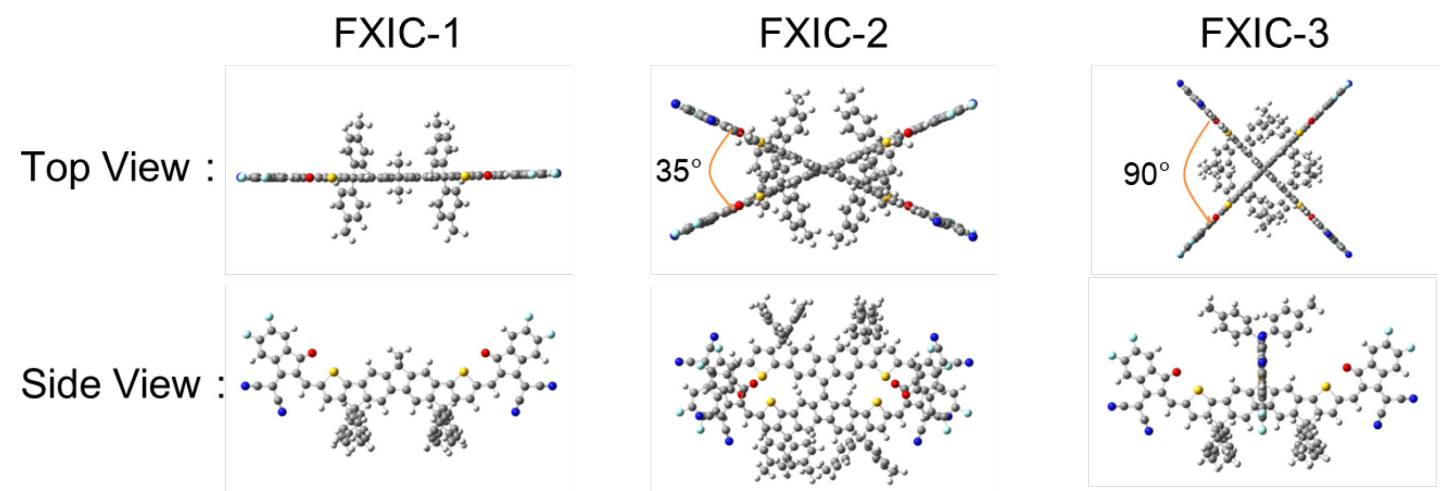

Figure S2. The optimal geometries of FXIC series (alkyls are simplified to methyl) calculated by Gaussian 09 program at B3LYP/6-31G* level. 

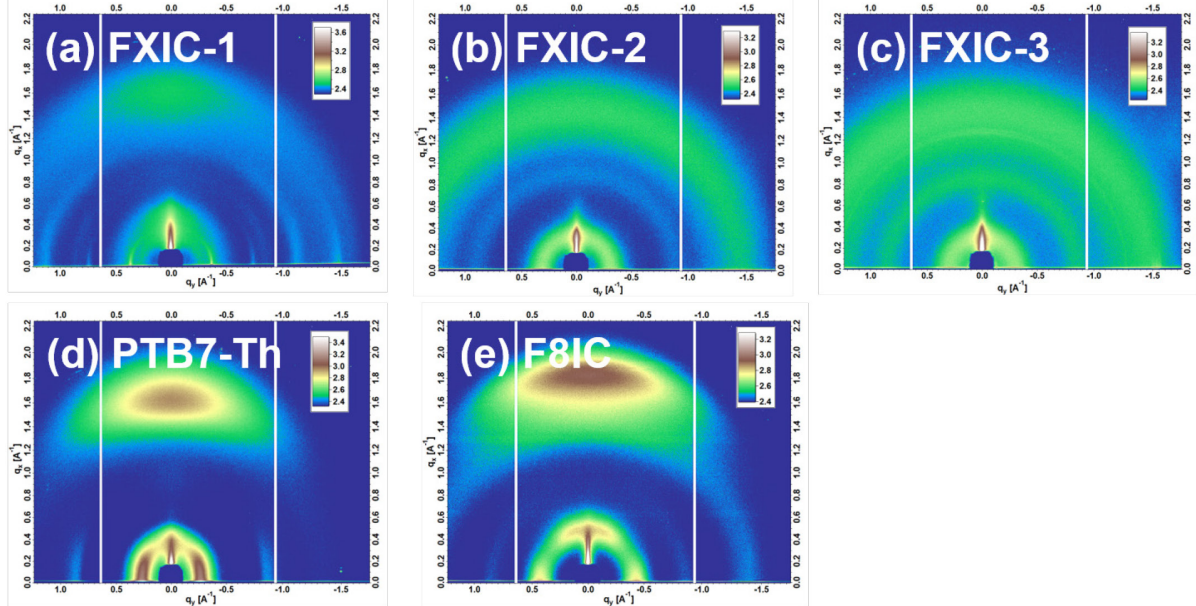

(f) out-of-plane

\section{(g) in-plane}
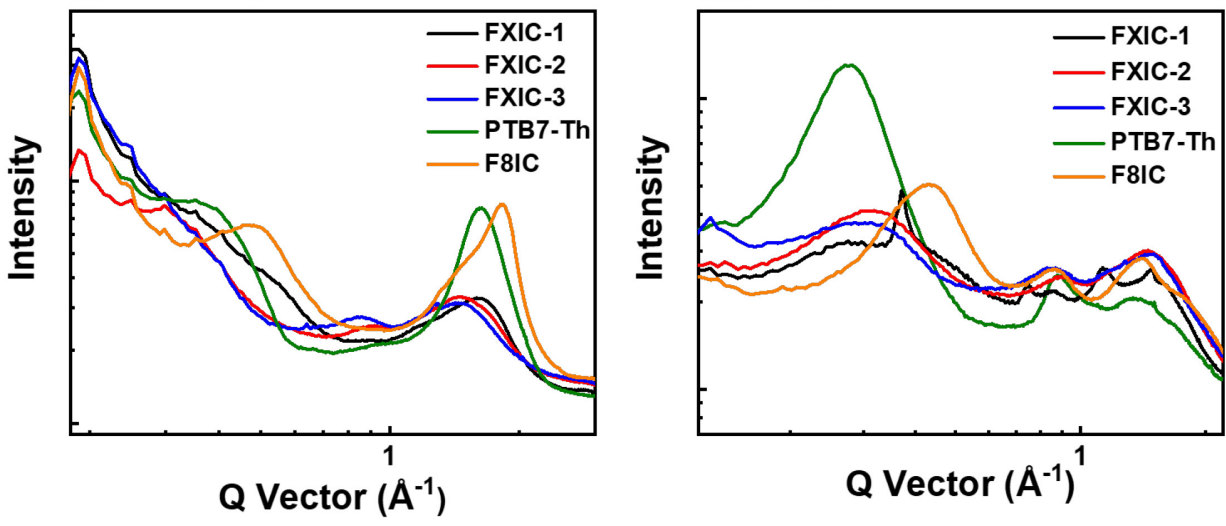

Figure S3. 2D GIWAXS patterns (a-e) and scattering profiles of out-of-plane (f) and in-plane (g) for FXIC series, PTB7-Th, and F8IC neat films.
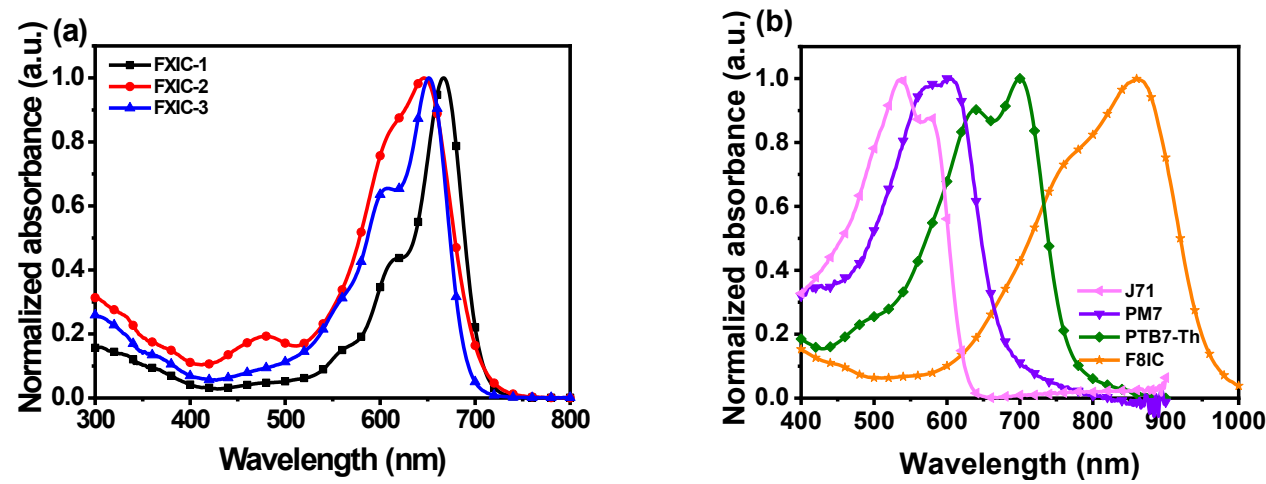

Figure S4. Absorption spectra of (a) FXIC series in chloroform solutions and (b) J71, PM7, PTB7-Th, and F8IC in neat films. 


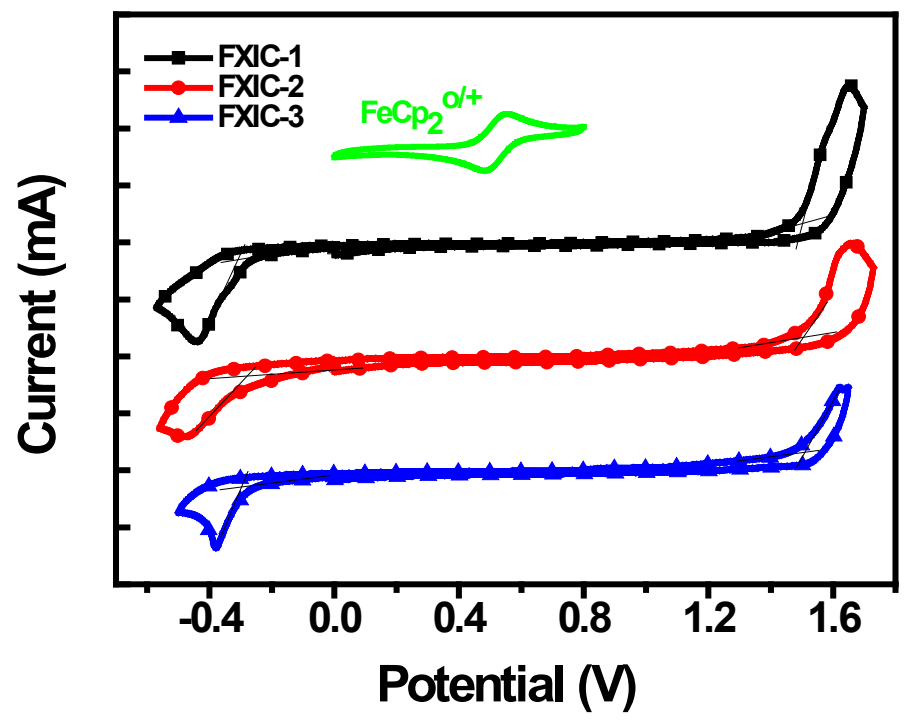

Figure S5. Cyclic voltammograms of FXIC series films in $\mathrm{CH}_{3} \mathrm{CN} / 0.1 \mathrm{M}$ $\left[{ }^{\mathrm{n}} \mathrm{Bu}_{4} \mathrm{~N}\right]^{+}\left[\mathrm{PF}_{6}\right]^{-}$at $100 \mathrm{mV} \mathrm{s}^{-1}$, the horizontal scale refers to an $\mathrm{Ag} / \mathrm{AgCl}$ electrode.

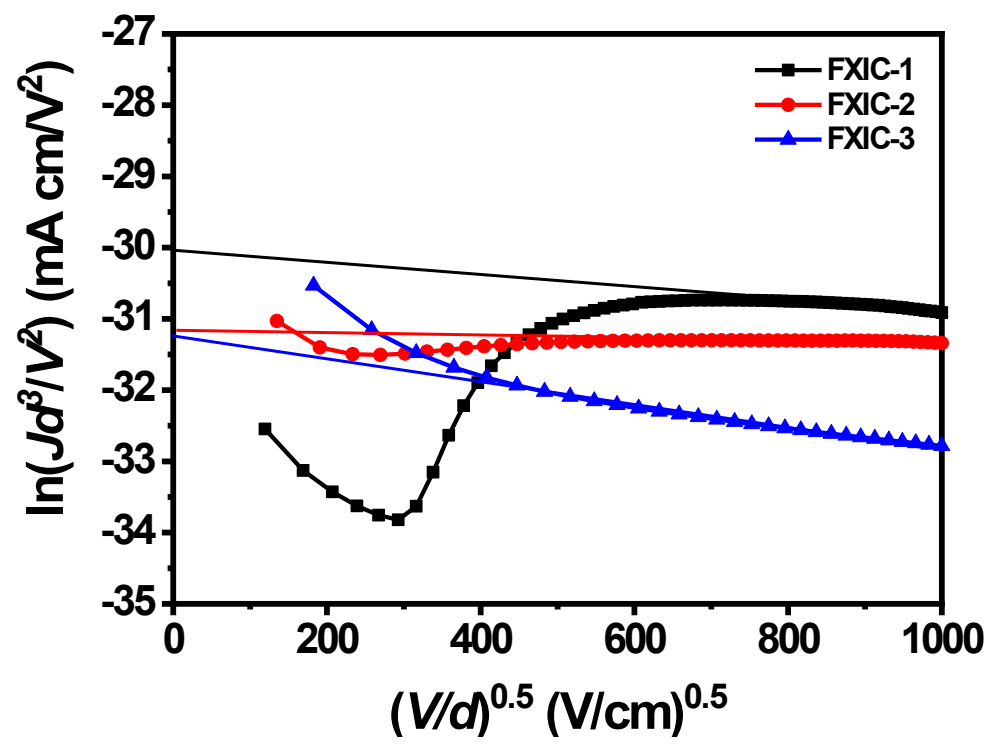

Figure S6. $J-V$ characteristics in the dark for electron-only devices based on FXIC series. 

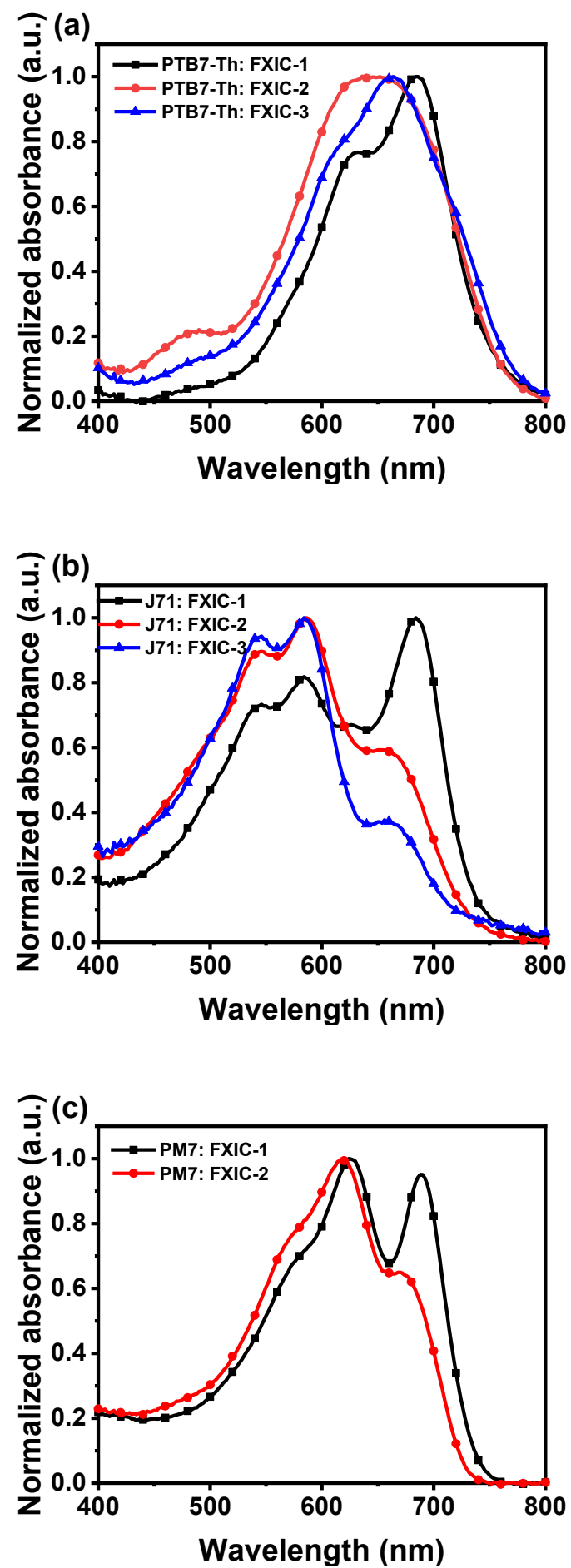

Figure S7. Absorption spectra of (a) PTB7-Th:FXIC-1 3 blends, (b) J71:FXIC-1 3 blends and (c) PM7:FXIC-1 2 blends. 

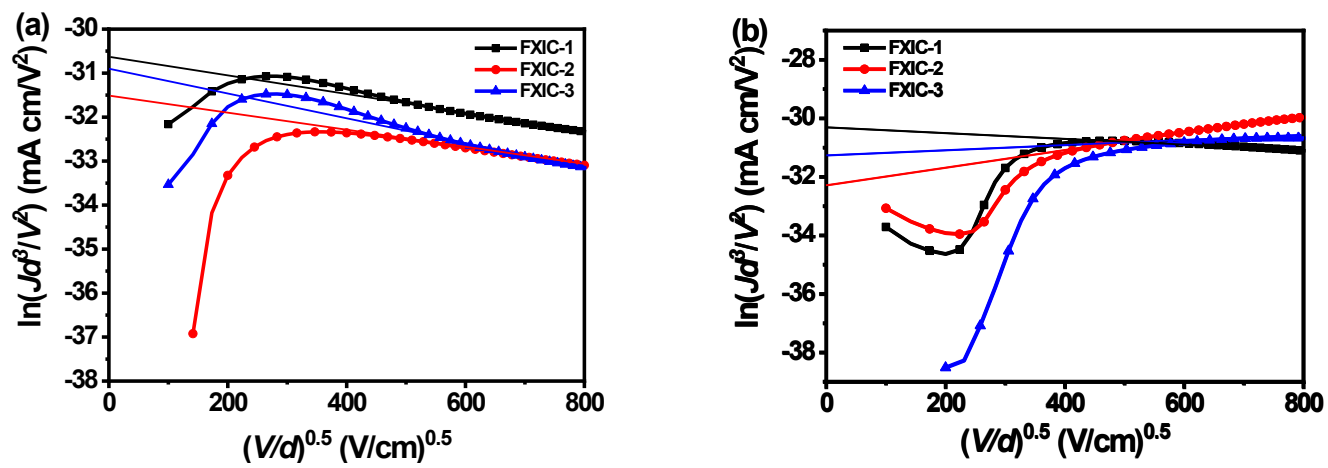

Figure S8. $J-V$ characteristics in the dark for (a) hole-only and (b) electron-only devices based on PTB7-Th:FXIC-1 3.
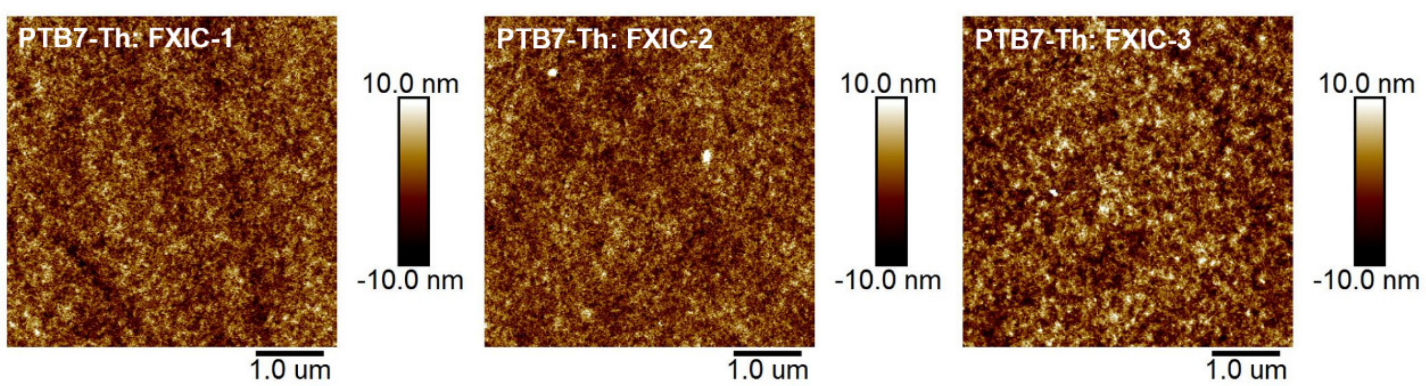

Figure S9. AFM height images of optimized PTB7-Th:FXIC-1 3 blend films.
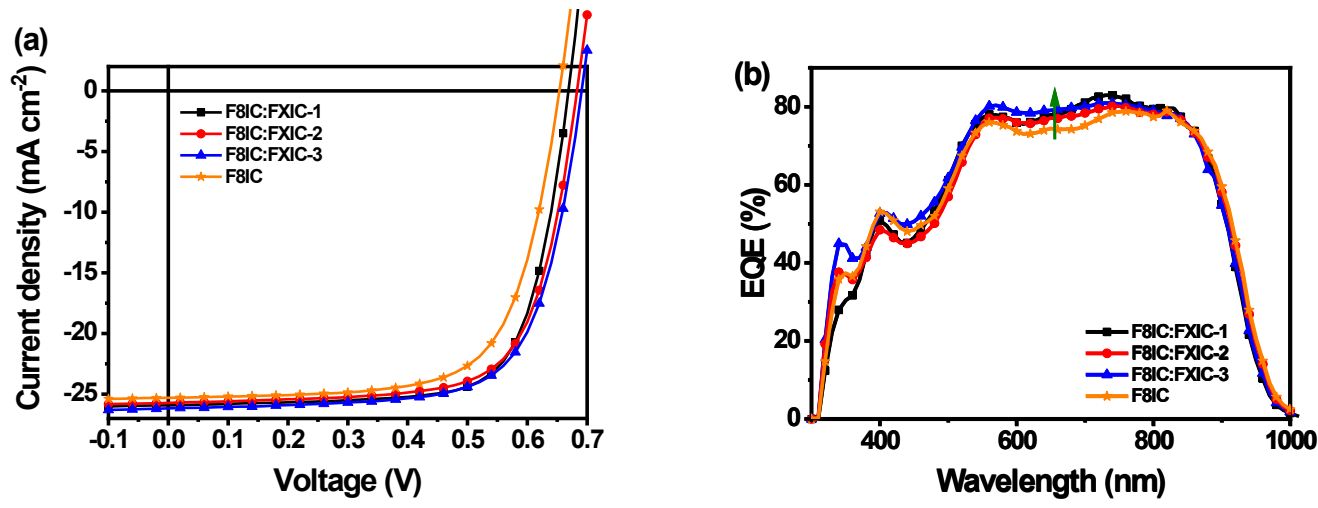

Figure S10. (a) $J-V$ characteristics and (b) EQE spectra of the optimized OSCs based on PTB7-Th:F8IC:FXIC series. 


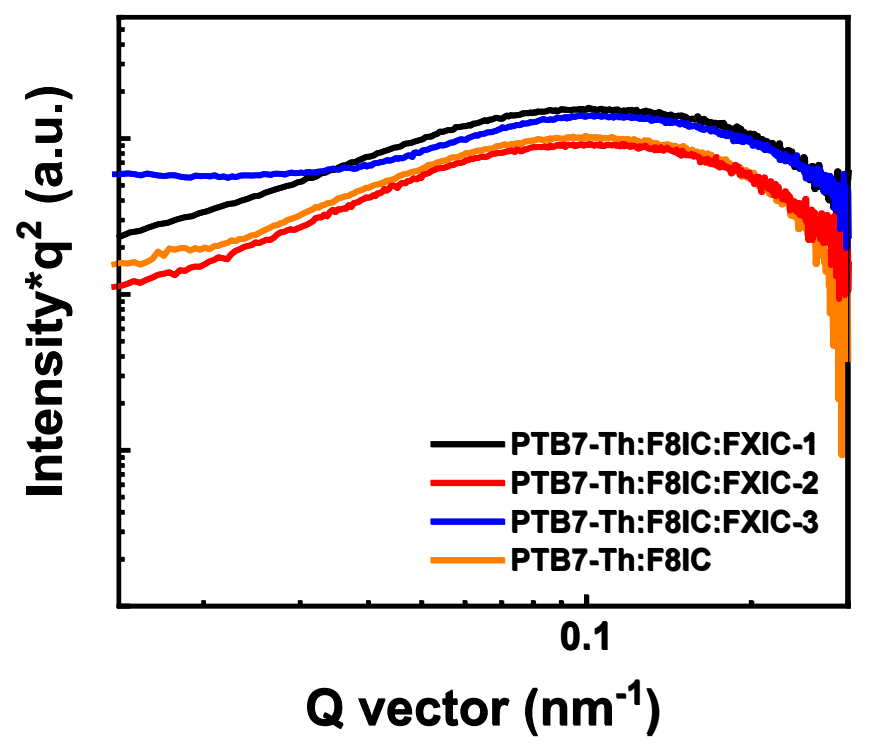

Figure S11. R-SoXS profiles in log scale for PTB7-Th:F8IC:FXIC series blend films. 
(a) PTB7-Th: F8IC: FXIC-1

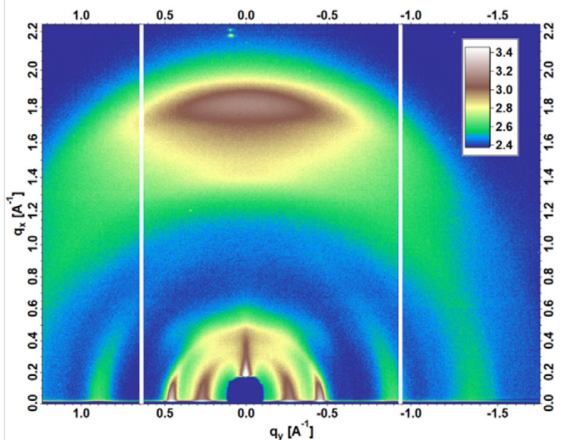

(c) PTB7-Th: F8IC: FXIC-3

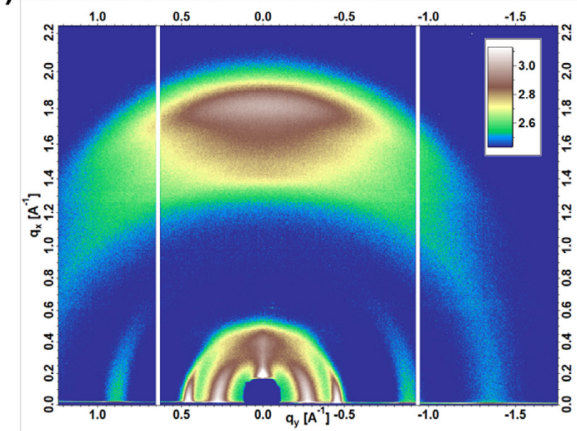

(e) out-of-plane -PCE10:F8IC:FXIC-1
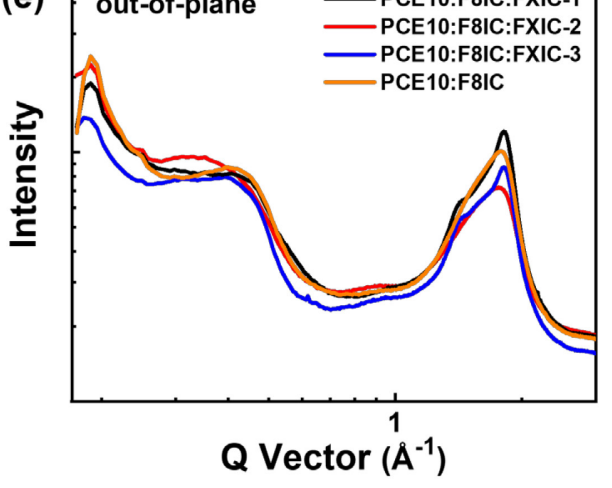

(b) PTB7-Th: F8IC: FXIC-2

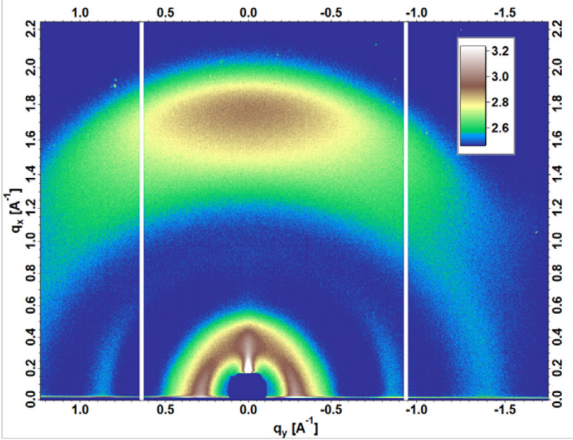

(d) PTB7-Th: F8IC
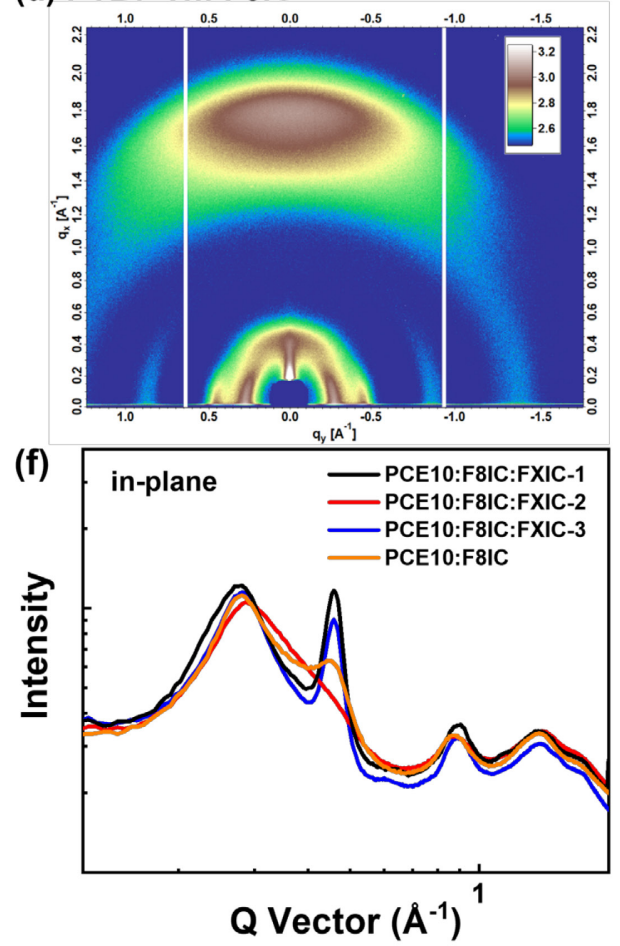

Figure S12. 2D GIWAXS patterns (a-d) and scattering profiles of out-of-plane (e) and in-plane (f) for PTB7-Th:F8IC:FXIC series blend films. 


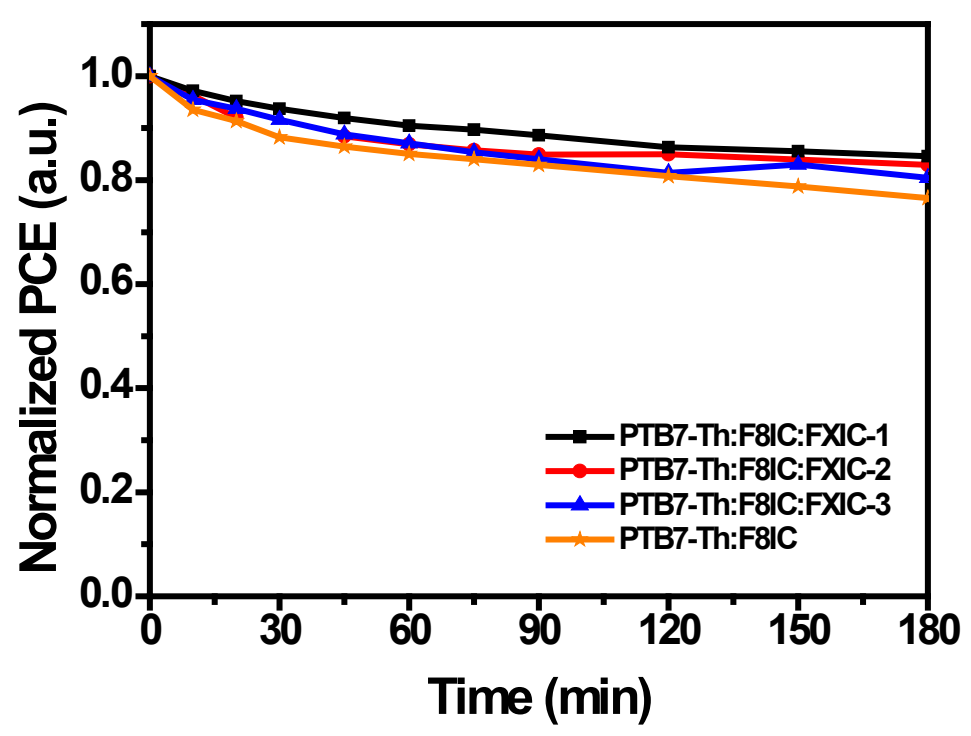

Figure S13. Light stability of optimized OSCs without encapsulation based on PTB7-Th:acceptor under continuous AM 1.5G illumination at $100 \mathrm{~mW} \mathrm{~cm}$.

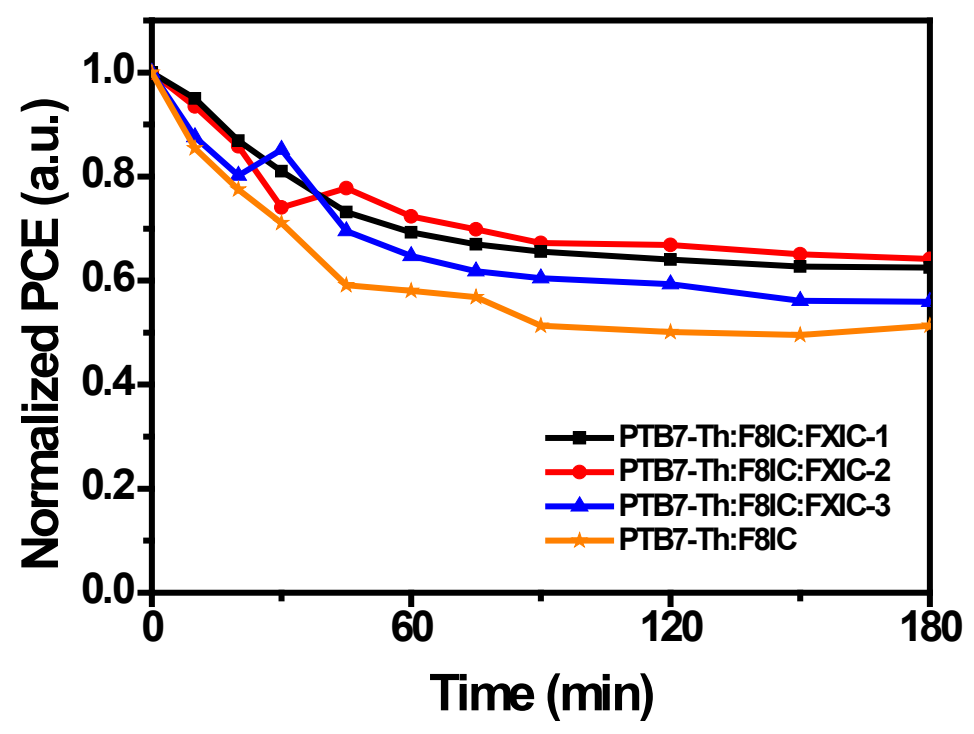

Figure S14. Thermal stability of optimized OSCs without encapsulation based on PTB7-Th:acceptor under continuous heating at $100{ }^{\circ} \mathrm{C}$. 
Table S1. The optimization of the devices based on PTB7-Th:FXIC-1 3.

\begin{tabular}{|c|c|c|c|c|c|c|}
\hline acceptor & $\begin{array}{c}\mathrm{D} / \mathrm{A} \\
(\mathrm{w} / \mathrm{w})\end{array}$ & additive & $\begin{array}{l}V_{\mathrm{OC}} \\
(\mathrm{V})\end{array}$ & $\begin{array}{c}J_{\mathrm{SC}} \\
\left(\mathrm{mA} \mathrm{cm}^{-2}\right)\end{array}$ & $\begin{array}{l}\text { FF } \\
(\%)\end{array}$ & $\begin{array}{l}\text { PCE } \\
(\%)\end{array}$ \\
\hline \multirow{6}{*}{ FXIC-1 } & $1: 1.2$ & - & 0.800 & 12.4 & 63.6 & 6.31 \\
\hline & $1: 1.5$ & - & 0.806 & 12.7 & 65.9 & 6.75 \\
\hline & $1: 1.8$ & - & 0.810 & 12.4 & 64.2 & 6.45 \\
\hline & $1: 1.5$ & $0.1 \% \mathrm{DIO}$ & 0.785 & 12.4 & 68.9 & 6.71 \\
\hline & $1: 1.5$ & $0.2 \% \mathrm{DIO}$ & 0.788 & 12.9 & 69.4 & 7.06 \\
\hline & $1: 1.5$ & $0.3 \%$ DIO & 0.782 & 12.6 & 66.4 & 6.54 \\
\hline \multirow{6}{*}{ FXIC-2 } & $1: 1.2$ & - & 0.724 & 9.92 & 64.8 & 4.65 \\
\hline & $1: 1.5$ & - & 0.722 & 10.2 & 63.5 & 4.68 \\
\hline & $1: 1.8$ & - & 0.719 & 10.0 & 62.6 & 4.50 \\
\hline & $1: 1.5$ & $0.1 \% \mathrm{DIO}$ & 0.714 & 10.2 & 63.6 & 4.63 \\
\hline & $1: 1.5$ & $0.2 \%$ DIO & 0.711 & 10.6 & 65.6 & 4.96 \\
\hline & $1: 1.5$ & $0.3 \%$ DIO & 0.712 & 10.2 & 64.7 & 4.70 \\
\hline \multirow{6}{*}{ FXIC-3 } & $1: 1.2$ & - & 0.759 & 10.9 & 68.1 & 5.63 \\
\hline & $1: 1.5$ & - & 0.755 & 11.2 & 67.6 & 5.72 \\
\hline & $1: 1.8$ & - & 0.749 & 11.0 & 66.9 & 5.51 \\
\hline & $1: 1.5$ & $0.1 \%$ DIO & 0.756 & 11.6 & 65.6 & 5.75 \\
\hline & $1: 1.5$ & $0.2 \%$ DIO & 0.760 & 12.0 & 67.4 & 6.12 \\
\hline & $1: 1.5$ & $0.3 \%$ DIO & 0.746 & 12.1 & 65.2 & 5.88 \\
\hline
\end{tabular}


Table S2. Device data of the optimized binary-blend OSCs based on J71 (PM7):

FXIC series.

\begin{tabular}{ccccccc}
\hline donor & acceptor & $\begin{array}{c}\mathrm{D} / \mathrm{A} \\
(\mathrm{w} / \mathrm{w})\end{array}$ & $\begin{array}{c}V_{\mathrm{OC}} \\
(\mathrm{V})\end{array}$ & $\begin{array}{c}J_{\mathrm{SC}} \\
\left(\mathrm{mA} \mathrm{cm}{ }^{-2}\right)\end{array}$ & $\begin{array}{c}\mathrm{FF} \\
(\%)\end{array}$ & $\begin{array}{c}\text { PCE } \\
(\%)\end{array}$ \\
\hline \multirow{2}{*}{$\mathrm{J}^{a}{ }^{a}$} & FXIC-1 & $1: 1$ & 0.895 & 15.2 & 68.8 & 9.37 \\
& FXIC-2 & $1: 1$ & 0.781 & 11.1 & 52.6 & 4.55 \\
& FXIC-3 & $1: 1$ & 0.822 & 11.8 & 63.4 & 6.12 \\
\hline \multirow{2}{*}{$\mathrm{PM}^{b}{ }^{b}$} & FXIC-1 & $1: 1$ & 1.00 & 14.7 & 69.0 & 10.2 \\
& FXIC-2 & $1: 1$ & 0.930 & 6.30 & 49.9 & 2.92 \\
\hline${ }^{a} 110{ }^{\circ} \mathrm{C}, 10 \mathrm{~min}^{b}{ }^{b} 0.2 \%(\mathrm{v} / \mathrm{v}) \mathrm{DIO}, 120{ }^{\circ} \mathrm{C}, 10 \mathrm{~min} ;{ }^{c}$ poor film quality. \\
\hline
\end{tabular}


Table S3. The device data of PTB7-Th:F8IC:FXIC series (D/A = 1: 1.5, w/w).

\begin{tabular}{|c|c|c|c|c|c|c|}
\hline acceptor $^{a}$ & $\begin{array}{l}\text { ratio } \\
(\mathrm{w} / \mathrm{w})\end{array}$ & $\begin{array}{l}V_{\mathrm{OC}} \\
(\mathrm{V})\end{array}$ & $\begin{array}{c}J_{\mathrm{SC}} \\
\left(\mathrm{mA} \mathrm{cm}^{-2}\right)\end{array}$ & $\begin{array}{l}\mathrm{FF} \\
(\%)\end{array}$ & $\begin{array}{l}\text { PCE } \\
(\%)\end{array}$ & $\begin{array}{c}\text { calc. } J_{\mathrm{SC}} \\
\left(\mathrm{mA} \mathrm{cm}^{-2}\right)\end{array}$ \\
\hline F8IC & - & 0.654 & 25.3 & 68.9 & 11.4 & 24.5 \\
\hline \multirow{7}{*}{ F8IC: FXIC-1 } & $1.4: 0.1$ & 0.662 & 25.1 & 68.4 & 11.4 & \multirow{7}{*}{25.0} \\
\hline & 1.3: 0.2 & 0.669 & 25.9 & 72.5 & 12.6 & \\
\hline & 1.2: 0.3 & 0.677 & 25.5 & 71.0 & 12.3 & \\
\hline & $1.1: 0.4$ & 0.677 & 26.1 & 68.0 & 12.0 & \\
\hline & 1.0: 0.5 & 0.684 & 24.5 & 70.3 & 11.8 & \\
\hline & $0.9: 0.6$ & 0.689 & 23.6 & 71.1 & 11.6 & \\
\hline & $0.7: 0.8$ & 0.698 & 23.8 & 68.4 & 11.4 & \\
\hline \multirow{7}{*}{ F8IC: FXIC-2 } & 1.4: 0.1 & 0.659 & 26.6 & 65.8 & 11.5 & \multirow{7}{*}{24.7} \\
\hline & 1.3: 0.2 & 0.665 & 25.7 & 67.8 & 11.6 & \\
\hline & 1.2: 0.3 & 0.664 & 26.1 & 68.5 & 11.8 & \\
\hline & 1.1: 0.4 & 0.678 & 25.8 & 70.1 & 12.2 & \\
\hline & 1.0: 0.5 & 0.683 & 25.7 & 70.5 & 12.4 & \\
\hline & $0.9: 0.6$ & 0.681 & 25.6 & 69.6 & 12.1 & \\
\hline & $0.7: 0.8$ & 0.680 & 23.6 & 62.8 & 10.1 & \\
\hline \multirow{7}{*}{ F8IC: FXIC-3 } & $1.4: 0.1$ & 0.660 & 25.6 & 67.3 & 11.4 & \multirow{7}{*}{25.3} \\
\hline & $1.3: 0.2$ & 0.667 & 25.2 & 69.5 & 11.7 & \\
\hline & 1.2: 0.3 & 0.666 & 25.6 & 69.8 & 11.9 & \\
\hline & 1.1: 0.4 & 0.691 & 26.2 & 70.2 & 12.7 & \\
\hline & 1.0: 0.5 & 0.688 & 26.2 & 69.1 & 12.5 & \\
\hline & 0.9: 0.6 & 0.691 & 24.5 & 71.8 & 12.1 & \\
\hline & $0.7: 0.8$ & 0.703 & 24.9 & 68.4 & 12.0 & \\
\hline
\end{tabular}




\section{References}

(S1) Dai, S.; Zhao, F.; Zhang, Q.; Lau, T. K.; Li, T.; Liu, K.; Ling, Q.; Wang, C.; Lu, X.; You, W.; Zhan, X. Fused Nonacyclic Electron Acceptors for Efficient Polymer Solar Cells. J. Am. Chem. Soc. 2017, 139, 1336-1343.

(S2) Dai, S.; Li, T.; Wang, W.; Xiao, Y.; Lau, T. K.; Li, Z.; Liu, K.; Lu, X.; Zhan, X. Enhancing the Performance of Polymer Solar Cells via Core Engineering of NIR-Absorbing Electron Acceptors. Adv. Mater. 2018, 30, No. 1706571.

(S3) Frisch, M. J.; Trucks, G. W.; Schlegel, H. B.; Scuseria, G. E.; Robb, M. A.; Cheeseman, J. R.; Scalmani, G.; Barone, V.; Mennucci, B.; Petersson, G. A.; Nakatsuji, H.; Caricato, M.; Li, X.; Hratchian, H. P.; Izmaylov, A. F.; Bloino, J.; Zheng, G.; Sonnenberg, J. L.; Hada, M.; Ehara, M.; Toyota, K.; Fukuda, R.; Hasegawa, J.; Ishida, M.; Nakajima, T.; Honda, Y.; Kitao, O.; Nakai, H.; Vreven, T.; Montgomery Jr., J. A.; Peralta, J. E.; Ogliaro, F.; Bearpark, M. J.; Heyd, J.; Brothers, E. N.; Kudin, K. N.; Staroverov, V. N.; Kobayashi, R.; Normand, J.; Raghavachari, K.; Rendell, A. P.; Burant, J. C.; Iyengar, S. S.; Tomasi, J.; Cossi, M.; Rega, N.; Millam, N. J.; Klene, M.; Knox, J. E.; Cross, J. B.; Bakken, V.; Adamo, C.; Jaramillo, J.; Gomperts, R.; Stratmann, R. E.; Yazyev, O.; Austin, A. J.; Cammi, R.; Pomelli, C.; Ochterski, J. W.; Martin, R. L.; Morokuma, K.; Zakrzewski, V. G.; Voth, G. A.; Salvador, P.; Dannenberg, J. J.; Dapprich, S.; Daniels, A. D.; Farkas, Ö.; Foresman, J. B.; Ortiz, J. V.; Cioslowski, J.; Fox, D. J.; Revision A.01 ed.; Gaussian, Inc.: Wallingford, CT, USA, 2009.

(S4) Becke, A. D. Density-Functional Exchange-Energy Approximation with Correct Asymptotic Behavior. Phys. Rev. A 1988, 38, 3098-3100.

(S5) Lee, C.; Yang, W.; Parr, R. G. Development of the Colle-Salvetti Correlation-Energy Formula into a Functional of the Electron Density. Phys. Rev. 
$B$ 1988, 37, 785-789.

(S6) Krishnan, R.; Binkley, J. S.; Seeger, R.; Pople, J. A. Self-Consistent Molecular Orbital Methods. XX. A Basis Set for Correlated Wave Functions. J. Chem. Phys. 1980, 72, 650-654.

(S7) Ilavsky, J.; Jemian, P. R. Irena: Tool Suite for Modeling and Analysis of Small-Angle Scattering. J. Appl. Crystallogr. 2009, 42, 347-353.

(S8) Nelson, A. Co-Refinement of Multiple-Contrast Neutron/X-ray Reflectivity Data using MOTOFIT. J. Appl. Crystallogr. 2006, 39, 273-276.

(S9) Beaucage, G. Approximations Leading to a Unified Exponential/Power-Law Approach to Small-Angle Scattering. J. Appl. Crystallogr. 1995, 28, 717-728.

(S10) Malliaras, G. G.; Salem, J. R.; Brock, P. J.; Scott, C. Electrical Characteristics and Efficiency of Single-layer Organic Light-emitting Diodes. Phys. Rev. B 1998, $58,13411$. 